\title{
Economics of College Sports: A Topical Reading List
}

\author{
Rodney Fort \\ University of Michigan
}

\begin{abstract}
In this reading list, journal articles and chapters from collected works of my acquaintance are organized under a set of college sports topic headings. Rather than the usual "economics" topics (demand, supply, market structure, labor, business and government), the aim is to inform a more general audience. There is no claim to exhaustive coverage and no detailed review of any topic that would guide future research. Instead, it is hoped that the list is helpful to those wishing to simply delve into economics offerings under topic headings that match a reader's interest.
\end{abstract}

\section{Introduction}

Rather than a more formal literature review, this paper provides a reading list of journal articles and chapters from collected works of my acquaintance. [There is now also a recent textbook-R.R. Grant, J. Leadly, and Z. Zygmont (2007), The Economics of Intercollegiate Sports (Hackensack, NJ: World Scientific Publishing Co.).] It was tempting to organize the works according to the usual progression of economics topics-demand, supply, market structure, labor markets, and business and government. However, in an attempt to appeal to the more general Journal of Intercollegiate Sport readership, the list is organized by descriptive college sports topics. It would surprise me if the reading list, even at 138 entries, is anywhere near exhaustive, even for the topics chosen. In addition, if the reader seeks the usual literature review that covers the contents of papers in detail, or suggests remaining future work to be done based on the current work, read no further. The aims of this presentation are simply to help those wishing to delve into economics offerings under the chosen topics; a kick-start if you will.

The topics are listed in alphabetical order with only one exception. The first topic is Athletics and the University: The Big Picture. If the reader is new to the area of economics of college sports, this is the place to start getting acquainted (in my opinion). The reader is cautioned to think broadly about their topic and to have a look at the list of topics below with such a broad view in mind.

If the reader's published work on economics of college sports isn't here, please let me know-remember, journal articles and chapters in collected works only, please. I try to keep up on such things and the list could be updated in a later 
version. The topic list is as follows, with a brief statement about what to expect in each category. I leave it to the reader to determine how each element of the reading list helps settle the issue that is inherent in the topics (although the titles sometimes reveal what the individual authors discover).

\section{Athletics and the University: The Big Picture}

As with the rest of the social scientists, writers on economics of college sports have contributed on the relationship between the university and its athletic department. This catch-all category contains these "big picture" thoughts but some of the listed papers also include bits and pieces of the rest of the topic titles.

\section{Advertising Value}

Athletic departments are believed to produce values for the university at large. Advertising value is one of them. The university is advertised to high-quality potential students, faculty, and staff when a team appears on TV, especially national $\mathrm{TV}$, and so much more so if the appearance is an attractive post-season bowl game.

\section{Applicant Pool}

Another possible value to the university at large, if the athletic department prospers and advertising value happens, is increasing the size of its applicant pool. With a larger pool, statistically, the chances for an improvement in the quality of the entering class increases.

\section{Attendance}

Attendance is one basic element of fan enjoyment and an important source of revenues for athletic departments. Interesting early work on attendance also covered a question that troubled the NCAA when it used to have control of top-level football TV contracts-Are attendance and TV viewing substitutes or complements?

\section{Coaching and Efficiency}

Economists use techniques that compare a given coach to the coaches that produced the most wins using similar talent. This allows statements on efficiency of coaching that hold team quality constant, one important factor in assessing the quality of coaches.

\section{Corruption}

The topic speaks for itself. Here the papers are about "tanking" in post-season tournaments (throwing entire games) and point shaving.

\section{Discrimination: Economic Outcomes}

The typical economic approach attempts to discover discrimination impacts on pay and hiring, after all of the other factors contributing to pay and hiring have already been held constant. Thus, the bulk of the work here is on coaches since players do not get paid (in the usual way). 


\section{Discrimination: Title IX}

The university role in college sports is highlighted by a focus on Title IX, the federal law governing equal opportunity in education. Issues range from cross-subsidy to controversy over the impacts on men's sports.

\section{Economic Impact on the Local Economy}

One of the major "town and gown" issues has always been the costs and benefits of college sports events for local communities. All but one of the papers listed here examines one part of the benefit-cost comparison, economic impact.

\section{Economic Value of Athletes to the Athletic Department}

College athletes are not paid in the typical way under the NCAA amateur requirement. But that doesn't stop economists from trying to estimate the revenue contribution of athletes to the athletic department. While there also are values created for the university at large by athletes, this topic focuses attention on the most basic element of the play-for-pay controversy.

\section{Faculty Quality}

As with advertising value and increasing the size of the applicant pool, another value to the university might be the quality of faculty drawn to universities with successful athletic programs (why should students have all the fun?). Thus, we find the "pigskins and publications" papers.

\section{Giving to the Athletic Department and the University}

Increased giving is the most obvious value that might flow to universities due to athletic success. Often there is confusion between alumni giving, athletic booster giving, and corporate sponsorship. However, the papers listed here all are quite careful on this distinction. And there can be no confusion in the one paper examining the relationship between athletic success and state appropriations to university budgets. This is also a difficult classification because a few of the papers mingle other topics (like the impact of NCAA sanctions, academic quality, and graduation rates)

\section{Graduation Rates}

While also a topic concerning the welfare of the student athlete, the main focus on graduation rates has been a simple comparison of athletes and their non-athlete student counterparts. The policy point of interest is whether or not athletic department and athlete concern about graduation is on par with the rest of the university.

\section{Information Efficiency: Rankings and Wagering}

Economists also are interested in the efficiency of information generated by economic processes. College sports are no exception and the topics are the information in team rankings and in wagering. 


\section{NCAA: Cartel Issues}

The large number of papers under this topic reflects the fascination among economists with industrial organization issues, especially ones that are not marketdetermined. Governance of college sports by conferences and the NCAA is just such a non-market outcome. The fundamental question is whether the NCAA is a cartel or not.

\section{NCAA: Competitive Balance}

Some sports economists are fascinated by competitive balance, that is, how evenly distributed is winning and access to the post-season. Actions by the NCAA have predictable consequences for competitive balance and the papers listed here attempt to test these predictions.

\section{NCAA: Rule Impacts}

Presumably, NCAA rules have impacts-scholarship restrictions, the amateur requirement, recruiting restrictions, and changes in the rules of play. A few of the papers in this section reveal the curious way that economists sometime frame an issue - changing the rules of play has an "economics of crime" application! The most well-known is changing the number of officials-will rule breaking go up because there is more monitoring or down because players know that the chances they will be caught have increased?

\section{NCAA: Voting Analysis}

Economists and fellow travelers in political science often identify self-interested motivations for voting. Here the object of analysis is voting on NCAA rules and regulations.

\section{Post-Season}

The topic name speaks for itself. The single paper here tries to lend the economic and business perspective to the choice of managing the football post-season through the BCS.

\section{Production}

Inputs are mixed with technology to produce outputs. The papers here assess this relationship for college sports_-players and coaching are mixed with facilities and strategy to produce winning.

\section{Recruiting Athletes}

Once again, the focus is on the impacts of an economic process. In this case, it is the process of recruiting college athletes. How does the process distribute talent and who collects the value this talent produces? 


\section{Role of Conferences}

In addition to the NCAA, member athletic departments also determine play and business through their conferences. Here, the role of conferences examined is their impact on competitive balance through revenue sharing.

\section{Television Issues}

TV is treated separately, rather than as just another type of demand and revenue source, or mingled in with the NCAA (despite much of the literature relating to the famous NCAA v. Board of Regents case, 1984). Since the industrial organization of college sports is unique, so are the TV arrangements, themselves.

\section{Value of College Compared to the Professional Draft}

The two papers in this final category examine motivations and payoffs to entering the draft versus staying in college.

\section{References by Topic}

\section{Athletics and the University: The Big Picture}

Borland, M.V., B.L. Goff, and R.W. Pulsinelli. 1992. "College Athletics: Financial Burden or Boon?" In G. Scully (ed.) Advances in the Economics of Sports Vol. 1 (Greenwich, CT: JAI Press Inc.), pp. 215-235.

Fizel, J.L., and R.W. Bennett. 2001. “College Sports.” In W. Adams and J. Brock (eds.) The Structure of American Industry $10^{\text {th }}$ ed. (Prentice Hall), pp. 325-350.

Fort, R., and J. Quirk. 1999. “The College Football Industry.” In J. Fizel, E. Gustafson, and L. Hadley (eds.) Sports Economics: Current Research (Westport, CT: Praeger), pp. 11-26.

Goff, B.L. 2000. "Effects of University Athletics on the University: A Review and Extension of Empirical Assessment." Journal of Sport Management, 14, 85-104.

Goff, B. 2004. "Effects of University Athletics on the University: A Review and Extension of Empirical Assessment." In J. Fizel and R. Fort (eds.) Economics of College Sports (Westport, CT: Praeger), pp. 65-86.

Mackey, C. 1995. "College Sports.” In W. Adams and J. Brock (eds.) The Structure of American Industry $9^{\text {th }} e d$. (Upper Saddle River, NJ: Prentice Hall), pp. 273-297.

Mahony, D.F., and T.D. DeSchriver. 2008. "The Big Business of College Sports in America." In B.R. Humphreys and D.R. Howard (eds.) The Business of Sports Vol. 1 (Westport, CT: Praeger), pp. 225-251.

Mixon, F.G., Jr., and L.J. Trevino. 2005. "From Kickoff to Commencement: The Positive Role of Intercollegiate Athletics in Higher Education." Economics of Education Review, 24, 97-102.

Noll, R.G. 1991. “The Economics of Intercollegiate Sports.” In J. Andre and D.N. James (eds.) Rethinking College Athletics (Philadelphia, PA: Temple University Press), pp. 197-209.

Noll, R.G. 1999. "The Business of College Sports and the High Costs of Winning." The Milken Institute Review, Third Quarter, 24-37.

Osborne, E. 2004. "Motivating College Athletics." In J. Fizel and R. Fort (eds.) Economics of College Sports (Westport, CT: Praeger), pp. 51-62.

Padilla, A., and D. Baumer. 1994. "Big-Time College Sports: Management and Economic Issues." Journal of Sport and Social Issues, 18, 123-143. 
Padilla, A., and J.L. Boucher. 1987. "On the Economics of Intercollegiate Athletic Programs." Journal of Sport and Social Issues, 11, 61-73.

Sandy, R., and P. Sloane. 2004. "Why Do U.S. Colleges Have Sports Programs?” In J. Fizel and R. Fort (eds.) Economics of College Sports (Westport, CT: Praeger), pp. 87-110.

Sheehan, R.G. 2000. "Academics, Athletics, and Finances." In W.S. Kern (ed.) The Economics of Sports (Kalamazoo, MI: W.E. Upjohn Institute for Employment Research), pp. 75-92.

\section{Advertising Value}

Bremmer, D.S., and R.G. Kesselring. 1993. "The Advertising Effect of University Athletic Success: A Reappraisal of the Evidence." Quarterly Review of Economics and Finance, 4, 409-421.

Smith, D.R. 2008. "Big-Time College Basketball and the Advertising Effect: Does Success Really Matter?" Journal of Sports Economics, 9, 387-406.

Tucker, I.B. 2005. "Big-Time Pigskin Success: Is There an Advertising Effect?" Journal of Sports Economics, 6, 222-227.

\section{Applicant Pool}

McCormick, R.E., and M. Tinsley. 1987. "Athletics versus Academics? Evidence from SAT Scores.” Journal of Political Economy, 95, 1103-1116.

Mixon, F.G., Jr., L.J. Trevino, and T.C. Minto. 2004. "Touchdowns and Test Scores: Exploring the Relationship between Athletics and Academics." Applied Economics Letters, 11, 421-424.

Murphy, R.G., and G.A. Trandel. 1994. "The Relation Between a University's Football Record and the Size of Its Applicant Pool.” Economics of Education Review, 13, 265-270.

Sigelman, L. 1995. "It's Academic- Or is it? Admissions Standards and Big-Time College Football." Social Science Quarterly, 76, 247-261.

Tucker, I.B., III, and L. Amato. 1993. "Does Big-Time Success in Football or Basketball Affect SAT Scores?" Economics of Education Review, 12, 177-181.

Tucker, I.B., and L.T. Amato. 2006. "A Reinvestigation of the Relationship between Big-Time Basketball Success and Average SAT Scores.” Journal of Sports Economics, 7, 428-440.

\section{Attendance}

DeSchriver, T.D., and P.E. Jensen. 2002. "Determinants of Spectator Attendance at NCAA Division II Football Contests." Journal of Sport Management, 16, 311-330.

Fizel, J.L., and R.W. Bennett. "The Impact of College Football Telecasts on College Football Attendance.” Social Science Quarterly, 70, 980-988.

Kaempfer, W.H., and P.L. Pacey. 1986. "Televising College Football: The Complementarity of Attendance and Viewing." Social Science Quarterly, 67, 176-185.

Price, D.I., and K.C. Sen. 2003. "The Demand for Game Day Attendance in College Football: An Analysis of the 1997 Division 1-A Season." Managerial \& Decision Economics, 24, 35-46.

\section{Coaching and Efficiency}

Clement, R.C., and R.E. McCormick. 1989. "Coaching Team Production.” Economic Inquiry, 27, 287-304.

Fizel, J.L., and M.P. D'itri. 1996. "Estimating Managerial Efficiency: The Case of College Basketball Coaches." Journal of Sport Management, 10, 435-445. 
Fizel, J.L., and M.P. D’itri. 1997. “Managerial Efficiency, Managerial Succession and Organizational Performance." Managerial and Decision Economics, 18, 295-308.

Fizel, J., and M.P. D'Itri. 2004. "Managerial Efficiency, Managerial Succession, and Organizational Performance.” In J. Fizel and R. Fort (eds.) Economics of College Sports (Westport, CT: Praeger), pp. 175-194.

\section{Corruption}

Balsdon, E., L. Fong, and M.A. Thayer. 2007. "Corruption in College Basketball? Evidence of Tanking in Postseason Conference Tournaments." Journal of Sports Economics, 8, 19-38.

Johnson, N. 2009. "NCAA 'Point Shaving' as an Artifact of Regression Effect and the Lack of Tie Games." Journal of Sports Economics, 10, 59-67.

Wolfers, J. 2006. "Point Shaving: Corruption in NCAA Basketball." American Economic Review: American Economic Association Papers and Proceedings, 96, 279-283.

\section{Discrimination: Economic Outcomes}

Brown, R.W., and R.T. Jewell. 1994. "Is There Customer Discrimination in College Basketball? The Premium Fans Pay for White Players." Social Science Quarterly, 75, 401-413.

Brown, R.W., and R.T. Jewell. 1995. "Race, Revenues, and College Basketball." The Review of Black Political Economy, 23, 75-90.

Cunningham, G.B., J.E. Bruening, and T. Straub. 2006. "The Underrepresentation of African Americans in NCAA Division I-A Head Coaching Positions." Journal of Sport Management, 20, 387-413.

Humphreys, B.R. 2000. "Equal Pay on the Hardwood: The Earnings Gap Between Male and Female NCAA Division I Basketball Coaches." Journal of Sports Economics, 1, 299-30.

Knoppers, A., B.B. Meyer, M. Ewing, and L. Forrest. 1989. "Gender and the Salaries of Coaches." Sociology of Sport Journal, 6, 348-361.

Mixon, F.G., Jr., and L.J. Trevino. 2004. "How Race Affects Dismissals of College Football Coaches." Journal of Labor Research, XXV, 645-656.

Upthegrove, T.R., V.J. Roscigni, and C.Z. Charles. 1999. "Big Money Collegiate Sports: Racial Concentration, Contradictory Pressures, and Academic Performance." Social Science Quarterly, 80, 718-737.

\section{Discrimination: Title IX}

Agthe, D.E., and R.E. Billings. 2000. "The Role of Football Profits in Meeting Title IX Gender Equity Regulations and Policy." Journal of Sport Management, 14, 28-40.

Anderson, D.J., and J.J. Cheslock. 2004. "Institutional Strategies to Achieve Gender Equity in Intercollegiate Athletics: Does Title IX Harm Male Athletes?" American Economic Review: American Economic Association Papers and Proceedings, 94, 307-311.

Carroll, K.A., and B.R. Humphreys. 2000. "Nonprofit Decision Making and Social Regulation: The Intended and Unintended Consequences of Title IX." Journal of Economic Behavior \& Organization, 43, 359-376.

Leeds, M.A., Y. Suris, and J. Durkin. 2004. "College Football and Title IX." In J. Fizel and R. Fort (eds.) Economics of College Sports (Westport, CT: Praeger), pp. 137-152.

Rishe, P.J. 1999. "Gender Gaps and the Presence and Profitability of College Football." Social Science Quarterly, 80, 702-717.

Zimbalist, A. 1997. "Gender Equity and the Economics of College Sport.” In W. Hendricks (ed.) Advances in the Economics of Sport Vol. 2 (Greenwich, CT: JAI Press Inc.), pp. 203-224. 


\section{Economic Impact on the Local Economy}

Baade, R.A., R.W. Baumann, and V.A. Matheson. 2008. "Assessing the Economic Impact of College Football Games on Local Economies.” Journal of Sports Economics, 9, 628-643.

Baade, R.A., and V.A. Matheson. 2004. "An Economic Slam Dunk or March Madness? Assessing the Economic Impact of the NCAA Basketball Tournament." In J. Fizel and R. Fort (eds.) Economics of College Sports (Westport, CT: Praeger), pp. 111-134.

Chang, S., and S. Canode. 2002. "Economic Impact of a Future College Football Program." Journal of Sport Management, 16, 239-246.

Johnson, B.K., and J.C. Whitehead. 2000. "Value of Public Goods from Sports Stadiums: The CVM Approach." Contemporary Economic Policy, 18, 48-58.

\section{Economic Value of Athletes to the Athletic Department}

Brown, R.W. 1993. "An Estimate of the Rent Generated by a Premium College Football Player.” Economic Inquiry, XXXI, 671-684.

Brown, R.W., and R.T. Jewell. 2004. "Measuring Marginal Revenue Product in College Athletics: Updated Estimates." In J. Fizel and R. Fort (eds.) Economics of College Sports (Westport, CT: Praeger), pp. 153-162.

Brown, R.W., and R.T. Jewel. 2006. "The Marginal Revenue Product of a Women's College Basketball Player." Industrial Relations, 45, 96-101.

\section{Faculty Quality}

Mixon, F.G., Jr. 1994. "Pigskins and Publications: An Alternative Perspective." Atlantic Economic Journal, 22, 71.

Shugart, W.F., III, R.D. Tollison, and B.L. Goff. 1986. "Pigskins and Publications." Atlantic Economic Journal, XIV, 46-50.

Tucker, I.B. 2004. "Pigskins and Publications Revisited." Applied Economics Letters, $11,843-845$.

\section{Giving to the Athletic Department and the University}

Baade, R.A., and J.O. Sundberg. 1996. "Fourth Down and Gold to Go? Assessing the Link between Athletics and Alumni Giving." Social Science Quarterly, 77, 789-803.

Baade, R.A., and J.O. Sundberg, J.O. 1996. "What Determines Alumni Generosity." Economics of Education Review, 15, 775-781.

Brooker, G., and T.D. Klastorin. 1981. "To the Victors Belong the Spoils? College Athletics and Alumni Giving." Social Science Quarterly, 62, 744-750.

Coughlin, C.C., and O.H. Erekson. 1984. "An Examination of Contributions to Support Intercollegiate Athletics." Southern Economic Journal, 51, 180-195.

Coughlin, C.C., and O.H. Erekson. 1985. "Contributions to Intercollegiate Athletic Programs: Further Evidence.” Social Science Quarterly, 65, 194-202.

Gaski, J.F., and M.J. Etzel. 1984. "Collegiate Athletic Success and Alumni Generosity: Dispelling the Myth." Social Behavior and Personality, 12, 29-38.

Grimes, P.W., and G.A. Chressanthis. 1994. "Alumni Contributions to Academics: The Role of Intercollegiate Sports and NCAA Sanctions." American Journal of Economics and Sociology, 53, 27-40.

Harrison, W.B. 1995. "College Relations and Fund-Raising Expenditures: Influencing the Probability of Alumni Giving to Higher Education." Economics of Education Review, $14,73-84$. 
Holmes, J.A., J.A. Meditz, and P.M. Sommers. 2008. "Athletics and Alumni Giving: Evidence from a highly Selective Liberal Arts College." Journal of Sports Economics, 9, 538-552.

Humphreys, B.R. 2006. "The Relationship between Big-Time College Football and State Appropriations for Higher Education.” International Journal of Sport Finance, 1, 119-128.

Humphreys, B.R., and M. Mondello. 2007. "Intercollegiate Athletic Success and Donations at NCAA Division I Institutions." Journal of Sport Management, 21, 265-280.

McCartha, D.C. 2002. "It Pays to Win." Business and Economic Review, 49, 3-12.

Rhoads, T.A., and S. Gerking. 2000. "Educational Contributions, Academic Quality, and Athletic Success." Contemporary Economic Policy, 18, 248-258.

Sack, A.L., and C. Watkins. 1985. "Winning and Giving." In D. Chu, J.O. Seagrave, and B.J. Becker (eds.) Sport and Higher Education (Champaign, IL: Human Kinetics Publisher, Inc.), pp. 299-306.

Sigelman, L., and S. Bookheimer. 1983. "Is It Whether You Win or Lose? Monetary Contributions to Big-Time College Athletic Programs." Social Science Quarterly, 64, 347-359.

Sigelman, L, and R. Carter. 1979. "Win One for the Giver? Alumni Giving and Big-Time College Sports.” Social Science Quarterly, 60, 284-294.

Stinson, J.L., and D.R. Howard. 2007. "Athletic Success and Private Giving to Athletic and Academic Programs at NCAA Institutions.” Journal of Sport Management, 21, 235-264.

Tucker, I.B. 2004. "A Reexamination of the Effect of Big-Time Football and Basketball Success on Graduation Rates and Alumni Giving Rates." Economics of Education Review, 23, 655-661.

\section{Graduation Rates}

Amato, L.H., J.M. Gandar, I.B. Tucker, and R.A. Zuber. 1996. "Bowls Versus Playoffs: The Impact on Football Player Graduation Rates in the National Collegiate Athletic Association." Economics of Education Review, 15, 187-195.

Amato, L.H., J.M. Gandar, and R.A. Zuber. 2001. "The Impact of Proposition 48 on the Relationship between Football Success and Football Player Graduation Rates.” Journal of Sports Economics, 2, 101-112.

DeBrock, L., W. Hendricks, and R. Koenker. 1996. "The Economics of Persistence: Graduation Rates of Athletes as Labor Market Choice." Journal of Human Resources, XXXI, 513-539.

DeBrock, L., W. Hendricks, and R. Koenker. 1997. "Graduation Rates of NFL Players.” In W. Hendricks (ed.) Advances in the Economics of Sport Vol. 2 (Greenwich, CT: JAI Press Inc.), pp. 225-241.

Fizel, J., and T. Smaby. 1999. "Participation in Collegiate Athletics and Academic Performance.” In J. Fizel, E. Gustafson, and L. Hadley (eds.) Sports Economics: Current Research (Westport, CT: Praeger), pp. 161-174.

Fizel, J., and T. Smaby. 2004. "Participation in College Athletics and Academic Performance.” In J. Fizel and R. Fort (eds.) Economics of College Sports (Westport, CT: Praeger), pp. 163-174.

Long, J.E., and S.B. Caudill. 1991. "The Impact of Participation in Intercollegiate Athletics on Income and Graduation." Review of Economics and Statistics, LXXIII, 525-530.

Maloney, M.T., and R.E. McCormick. 1993. "An Examination of the Role that Intercollegiate Athletic Participation Plays in Academic Achievement: Athletes' Feats in the Classroom.” Journal of Human Resources, 29, 555-570.

Rishe, P.J. 2003. "A Reexamination of How Athletic Success Impacts Graduation Rates: Comparing Student-Athletes to All Other Undergraduates." American Journal of Economics and Sociology, 62, 407-427.

Tucker, I.B., III. 1992. "The Impact of Big-Time Athletics on Graduation Rates." Atlantic Economic Journal, 20, 65-72. 


\section{Information Efficiency: Rankings and Wagering}

Fair, R.C., and J.F. Oster. 2007. "College Football Rankings and Market Efficiency.” Journal of Sports Economics, 8, 3-18.

Harbaugh, R., and T. Klumpp. 2005. "Early Round Upsets and Championship Blowouts." Economic Inquiry, 43, 316-329.

Paul, R.J., A.P. Weinbach, and P. Coate. 2007. "Expectations and Voting in the NCAA Football polls: The Wisdom of Point Spread Markets." Journal of Sports Economics, 8, 412-424.

Woodland, B.M., and L.M. Woodland. 1991. "The Effects of Risk Aversion on Wagering: Point Spread versus Odds.” Journal of Political Economy, 99, 638-653.

\section{NCAA: Cartel Issues}

Begley, G. 1985. "The Current Economic Status of Intercollegiate Sport.” In D. Chu, J.O. Seagrave, and B.J. Becker (eds.) Sport and Higher Education (Champaign, IL: Human Kinetics Publisher, Inc.), pp. 287-297.

Blair, R.D., and R.E. Romano. 1997. "Collusive Monopsony in Theory and Practice: The NCAA." Antitrust Bulletin, 42, 681-719.

DeBrock, L., and W. Hendricks, W. 1997. "Setting Rules in the NCAA Cartel." In W. Hendricks (ed.) Advances in the Economics of Sport Vol. 2 (Greenwich, CT: JAI Press Inc.), pp. 179-202.

Depken, C.A., II, and D.P. Wilson. 2004. "The Impact of Cartel Enforcement in NCAA Division I-A Football." In J. Fizel and R. Fort (eds.) Economics of College Sports (Westport, CT: Praeger), pp. 225-244.

DeSchriver, T.D., and D.K. Stotlar. 1996. "An Economic Analysis of Cartel Behavior within the NCAA." Journal of Sport Management, 10, 388-400.

Kahn, L.M. 2007. "Cartel Behavior and Amateurism in College Sports." Journal of Economic Perspectives, 21, 209-226.

Koch, J.V. 1971. "The Economics of 'Big Time' Intercollegiate Athletics.” Social Science Quarterly, 52, 248-260.

Koch, J.V. 1973. “A Troubled Cartel: The NCAA.” Law \& Contemporary Problems, 38, 135-150.

Koch, J.V. 1983. "Intercollegiate Athletics: An Economic Explanation.” Social Science Quarterly, 64, 360-374.

Koch, J.V., and W.M. Leonard, II. 1978. "The NCAA: A Socio-economic Analysis: The Development of the College Sports Cartel from Social Movement to Formal Organization." American Journal of Economics and Sociology, 37, 225-239.

Main, R.S., and W.K. Templeton. 1994. "NCAA Regulation of Non-Revenue Sports: Implications of A General Cartel Model." Midwestern Journal of Business and Economics, 9, 21-34.

Maxcy, J.G. 2004. "The 1997 Restructuring of the NCAA: A Transactions Cost Explanation." In J. Fizel and R. Fort (eds.) Economics of College Sports (Westport, CT: Praeger), pp. 11-34.

McKenzie, R.B., and T. Sullivan. 1987. "Does the NCAA Exploit College Athletes? An Economics and Legal Interpretation." Antitrust Bulletin, 32, 373-399.

McKenzie, R.B., and G. Tullock. 1989. "Does the NCAA Exploit College Athletes?" In R.B. McKenzie and G. Tullock (eds.) The Best of the New World of Economics (Homewood, IL: Irwin), pp. 352-373.

\section{NCAA: Competitive Balance}

Depken, C.A., II, and D.P. Wilson. 2004. "Institutional Change in the NCAA and Competitive Balance in Intercollegiate Football.” In J. Fizel and R. Fort (eds.) Economics of College Sports (Westport, CT: Praeger), pp. 197-210. 
Depken, C.A., II, and D.P. Wilson. 2006. "NCAA Enforcement and Competitive Balance in College Football." Southern Economic Journal, 72, 826-845.

Eckard, E.W., 1998. "The NCAA Cartel and Competitive Balance in College Football." Review of Industrial Organization, 13, 347-369.

Sutter, D., and S. Winkler. 2003. "NCAA Scholarship Limits and Competitive Balance in College Football." Journal of Sports Economics, 4, 3-18.

\section{NCAA: Rule Impacts}

Baird, K. 2004. "Dominance in College Football and the Role of Scholarship Restrictions." Journal of Sport Management, 18, 217-235.

Goff, B.L., W.F. Shugart, III, and R.D. Tollison. 1988. "Disqualification by Decree: Amateur Rules as Barriers to Entry." Journal of Institutional and Theoretical Economics, 144, 515-523.

Humphreys, B.R., and J.E. Ruseski. 2006. "Financing Intercollegiate Athletics: The Role of Monitoring and Enforcing NCAA Recruiting Regulations." International Journal of Sport Finance, 1, 151-161.

McCormick, R.E., and R.D. Tollison. 1984. "Crime on the Court." Journal of Political Economy, 92, 223-235.

Preston, I., and S. Szymanski. 2003. "Cheating in Contests." Oxford Review of Economic Policy, 19, 612-624.

Rees, D.I., and K.T. Schnepel. 2009. “College Football Games and Crime.” Journal of Sports Economics, 10, 68-87.

Winfree, J.A., and J.J. McCluskey. 2008. "Incentives for Post-Apprehension Self-Punishment: University Self-Sanctions for NCAA Infractions." International Journal of Sport Finance, 3, 196-209.

\section{NCAA: Voting Analysis}

Brown, R.W., and R.T. Jewell. 1996. "Rent-Seeking in Higher Education: Voting on Academic Requirements." Public Choice, 88, 103-113.

DeBrock, L., and W. Hendricks. 1996. "Roll Call Voting in the NCAA." Journal of Law, Economics, \& Organization, 12, 497-516.

Jewell, R.T., and R.K. Brown. 1999. "NCAA Voting on Proposition 42.” The Researcher, 16, 91-102.

Laband, D.N., R. Pandit, A.M. Laband, and J.P. Sophocleus. 2008. "Pigskins and Politics: Linking Expressive Behavior and Voting." Journal of Sports Economics, 9, 553-560.

\section{Post-Season}

Mondello, M. 2008. "The College Football Postseason Mess: Economic Perspectives.” In B.R. Humphreys and D.R. Howard (eds.) The Business of Sports Vol. 3 (Westport, CT: Praeger), pp. 167-189.

\section{Production}

Berri, D.J. 2004. “Is There a Short Supply of Tall People in the College Game?” In J. Fizel and R. Fort (eds.) Economics of College Sports (Westport, CT: Praeger), pp. 211-224.

Kotlyarenko, D., and R.G. Ehrenberg. 2000. "Ivy League Athletic Performance: Do Brains Win?" Journal of Sports Economics, 1, 139-150.

Shughart, W.F., II, and B.L. Goff. 1992. "Fields of Dreams: On the Construction of Professional Baseball Talent in Colleges and the Minor Leagues." In G. Scully (ed.) Advances in the Economics of Sports Vol. 1 (Greenwich, CT: JAI Press Inc.), pp. 91-114. 


\section{Recruiting Athletes}

Brown, R.W. 1994. "Measuring Cartel Rents in the College Basketball Player Recruitment Market." Applied Economics, 26, 27-34.

Dumond, J.M., A.K. Lynch, and J. Platania. 2008. "An Economic Model of the College Football Recruiting Process." Journal of Sports Economics, 9, 67-87.

Fizel, J.L., and R.W. Bennett. 1996. "Telecasts and Recruiting in NCAA Division I Football: The Impact of Altered Property Rights.” Journal of Sport Management, 10, 359-372.

Langelett, G. 2003. "The Relationship Between Recruiting and Team Performance in Division 1A College Football." Journal of Sports Economics, 4, 240-245.

Leonard, J., and J. Prinzinger. 1984. "An Investigation into the Monopsonistic Market Structure of Division One NCAA Football and Its Effect on College Football Players." Eastern Economic Journal, 10, 455-467.

\section{Role of Conferences}

Brown, R.W. 1994. "Incentives and Revenue Sharing in College Football: Spreading the Wealth or Giving away the Game?" Managerial \& Decision Economics, 15, 471-486.

Quirk, J. 2004. "College Football Conferences and Competitive Balance.” Managerial \& Decision Economics, 25, 63-75.

\section{Television Issues}

Bennett, R.W., and J.L. Fizel. 1995. "Telecast Deregulation and Competitive Balance: Regarding NCAA Division I Football." American Journal of Economics and Sociology, 54, 183-199.

Campbell, N.D., T.M. Rogers, and R.Z. Finney. 2007. "Evidence of Television Exposure Effects in AP Top 25 College Football Rankings." Journal of Sports Economics, 8, 425-434.

Gulland, E.D., J.P. Byrne, and S.E. Steinbach. 1984. "Intercollegiate Athletics and Television Contracts: Beyond Economic Justifications in Antitrust Analysis of Agreements among Colleges." Fordham Law Review, 52, 717-731.

Hochberg, P., and I. Horowitz. 1973. "Broadcasting and CATV: The Beauty and the Bane of Major College Football." Law \& Contemporary Problems, 38, 112-128.

Mawson, M.L., and W.T. Bowler, III. 1989. "Effects of the 1984 Supreme Court Ruling on the Television Revenues of NCAA Division I Football Programs." Journal of Sport Management, 3, 79-89.

Pacey, P.L., and E.D. Wickham. 1985. "College Football Telecasts: Where Are They Going?" Economic Inquiry, 23, 93-113.

\section{Value of College Compared to the Professional Draft}

Groothuis, P.A., J.R. Hill, and T.J. Perri. 2007. "Early Entry in the NBA Draft: the Influence of Unraveling Human Capital, and Option Value." Journal of Sports Economics, $8,223-243$.

Winfree, J.A., and C.J. Molitor. 2007. "The Value of College: Drafted High School Baseball Players." Journal of Sports Economics, 8, 378-393. 